\title{
溶出処理によるムライト質多孔体の製造
}

\author{
阿部久雄 - 関 秀哉 - 福永昭夫 ·江頭 誠* \\ ( 長崎県窯業試験場, 859-37 長崎県東彼杵郡波佐見町井石鄉 2240 ) \\ * 長崎大学工学部材料工学科, 852 長崎市文教町 1-14
}

\section{Preparation of Porous Mullite Ceramics by Leaching Method}

\author{
Hisao ABE, Hideya SEKI, Akio FUKUNAGA and Makoto EGASHIRA*
}

$\left(\begin{array}{l}\text { Nagasaki Prefectural Ceramic Research Institute, 2240, Iseki-go, Hasami-cho, Higashisonogi-gun, Nagasaki } \\ \text { * Department of Materials Science and Engineering, Faculty of Engineering, Nagasaki University, } \\ \text { 1-14, Bunkyo-machi, Nagasaki-shi } 852\end{array}\right)$

Porous mullite ceramics were prepared by leaching glassy matrixes with a mixed acid from the sintered samples with compositions $\mathrm{Al}_{2} \mathrm{O}_{3} / \mathrm{SiO}_{2}=1 / 3.3,1 / 2,1 / 1$ and $3 / 2$ in molar ratio. The shape of the mullite crystals were granular for the samples from submicron powder mixtures of $\mathrm{Al}_{2} \mathrm{O}_{3}$ and $\mathrm{SiO}_{2}$ sintered at $1400^{\circ}-1600^{\circ} \mathrm{C}$. Addition of $\mathrm{CaO}, \mathrm{MgO}, \mathrm{BaO}$, $\mathrm{TiO}_{2}$, or $\mathrm{Fe}_{2} \mathrm{O}_{3}(5 \mathrm{wt} \%)$ to the $\mathrm{Al}_{2} \mathrm{O}_{3}-\mathrm{SiO}_{2}$ system with composition $\mathrm{Al}_{2} \mathrm{O}_{3} / \mathrm{SiO}_{2}{ }^{\circ}=1 / 3.3$ promoted the formation of elongated or needle-like mullite crystals. Effects of these oxides on the formation of mullite grains with high aspect ratio were discussed on the basis of the ternary phase diagrams. Average pore sizes of the leached porous mullite ceramics were in the range of 0.4-3 $\mu \mathrm{m}$, and became larger in the order of $\mathrm{CaO}>\mathrm{MgO}>\mathrm{Fe}_{2} \mathrm{O}_{3}>$ none $>\mathrm{BaO}>\mathrm{TiO}_{2}$ in additives. The pore size measured by mercury-penetration method agreed with that observed by SEM.

[Received October 19, 1988; Accepted March 16, 1989]

Key-words : Mullite, Porous ceramics, Leaching, Pore size distribution, Elongation of crystals

\section{1. 緒 言}

セラミックスの多孔体は機械的強度・耐熱性・化学的 安定性に優れており, 化学工業・食品醸造・建設等, 各 方面での利用が検討されている(1) 3). セラミックスの多 孔体を製造するには，七ラミックス粉体の初期焼結に よってできる気孔を利用する方法や, 可然性の気孔形成 材を添加して焼成時にこれを消失させ，気孔を形成する 方法などが一般的である(4) 6).

著者らは $\mathrm{Al}_{2} \mathrm{O}_{3}$ と $\mathrm{SiO}_{2}$ を主成分とするセラミックス の焼成体中にしばしばよく発達したムライト(3 $\left.\mathrm{Al}_{2} \mathrm{O}_{3} \cdot 2 \mathrm{SiO}_{2}\right)$ の結晶が認められることに着目し, その マトリックスを酸処理により除いてムライト質の多孔体 を製造することを考えた。本稿では，サブミクロンの粉 体を出発原料とした $\mathrm{Al}_{2} \mathrm{O}_{3}-\mathrm{SiO}_{2} 2$ 成分系及び $\mathrm{Al}_{2} \mathrm{O}_{3}-\mathrm{SiO}_{2}-\mathrm{M}_{x} \mathrm{O}_{y} 3$ 成分系 $\left(\mathrm{M}_{x} \mathrm{O}_{y}: \mathrm{MgO}, \mathrm{CaO}, \mathrm{BaO}\right.$, $\left.\mathrm{TiO}_{2}, \mathrm{Fe}_{2} \mathrm{O}_{3}\right)$ 試料の $1400^{\circ} \sim 1600^{\circ} \mathrm{C}$ における焼成体中 の構成相の変化, 並びにこの焼成体のマトリックスを酸 処理することによって得られるムライト質の多孔体の組 織と細孔分布について検討した.

\section{2. 実験方法}

\section{1 出発原料}

$\mathrm{SiO}_{2}$ 原料としては純度 $99.7 \mathrm{wt} \%$ のケイ石粉（ $\alpha$-石 英, 日窒工業製）をアトリッションミルで $120 \mathrm{~h}$ 粉砕し

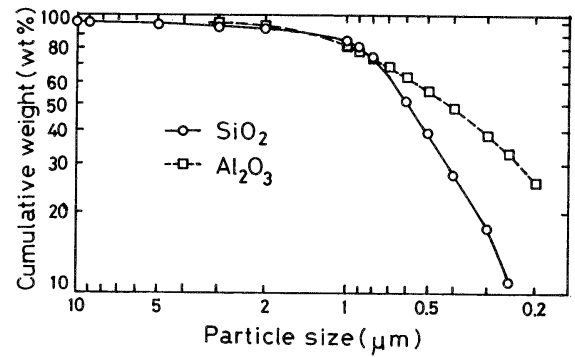

Fig. 1. Particle size distribution of starting materials.

平均粒径 $0.6 \mu \mathrm{m}$ にしたもの，また $\mathrm{Al}_{2} \mathrm{O}_{3}$ 原料としては 純度 $99.6 \mathrm{wt} \%$ のギブサイト仮焼物（ $\rho$-アルミナ，住友 化学工業製・商品名：水硬性アルミナ）をそれぞれ用い た. 粒度分布を図 1 に示す. 金属酸化物としては $\mathrm{TiO}_{2}$, $\mathrm{Fe}_{2} \mathrm{O}_{3}$ については試薬特級をそのまま用いたが， $\mathrm{MgO}$ は水酸化物を, また $\mathrm{CaO}, \mathrm{BaO}$ については炭酸塩の試 薬特級を用いた。

\section{2 供試組成}

$\mathrm{Al}_{2} \mathrm{O}_{3}-\mathrm{SiO}_{2} 2$ 成分系試料（以下 2 成分系亡記す）に ついては, $\mathrm{Al}_{2} \mathrm{O}_{3} / \mathrm{SiO}_{2}$ 比がモル比で $1 / 3.3,1 / 2,1 / 1$, $3 / 2$ の 4 種の組成を選んだ。また $\mathrm{Al}_{2} \mathrm{O}_{3}-\mathrm{SiO}_{2}-\mathrm{M}_{x} \mathrm{O}_{y} 3$ 成分系試料 (以下 3 成分系上記す) は上記の $\mathrm{Al}_{2} \mathrm{O}_{3} / \mathrm{SiO}_{2}=1 / 3.3$ の試料に既述の金属化合物を酸化物 換算でそれぞれ $5 \mathrm{wt} \%$ 添加したものを実験に供した。 


\section{3 試験体の作製}

上記の組成の調合物をアルミナ製のポットミルにとり 水分 $50 \mathrm{wt} \%$ の水系懸濁液としたのち $24 \mathrm{~h}$ 混合・粉砕 した。この懸濁液をセッコウ板上に展開・脱水して板状 の成形体とし $105^{\circ} \mathrm{C}$ で乾燥後, $1400^{\circ}, 1500^{\circ}, 1600^{\circ} \mathrm{C}$ の各温度で $1 \mathrm{~h}$ 焼成した. 昇温速度は $100^{\circ} \mathrm{C} / \mathrm{h}$ とし降温 は炉冷により行った。

\section{4 焼成体の構成相}

粉末 X線回折に上り焼成体における構成相の同定を行 うとともに, 内部標準としてフルオライト $\left(\mathrm{CaF}_{2}\right)$ を $10 \mathrm{wt} \%$ 添加し，ムライト・ $\alpha$-クリストバライト・ $\alpha$-ア ルミナの相対量の変化を調べた.

\section{5 酸処理及び組織の評価}

焼成体を混酸 $\left(\mathrm{HF}, \mathrm{HCl}, \mathrm{H}_{2} \mathrm{SO}_{4}\right.$ 及び $\mathrm{H}_{2} \mathrm{O}$ の等量混 合物）中に $24 \mathrm{~h}$ 浸漬し, ガラス質のマトリックスを溶 出した. 水洗・乾燥後, 破断面の組織を走查型電子顕微 鏡 (SEM) によって観察した.またこの試料の細孔分 布を水銀圧入式の細孔分布測定器によって測定した. 細 孔径は試料に対する水銀の接触角 $\theta$ を $140^{\circ}$, 水銀の表 面張力 $\gamma$ を $480 \mathrm{dyn} / \mathrm{cm}$ とし次式によって計算した。 こ こに $r$ は細孔半径 $(\AA), p$ は圧力 $\left(\mathrm{kg} / \mathrm{cm}^{2}\right)$ である7).

$$
r=\frac{-2 \gamma \cos \theta}{p}
$$

\section{3. 結果及び考察}

\section{$3.1 \mathrm{Al}_{2} \mathrm{O}_{3}-\mathrm{SiO}_{2} 2$ 成分系における組成の影響}

2 成分系の各焼成温度における構成相の変化をムライ ト， $\alpha$-クリストバライト， $\alpha$-アルミナについて図 2 に示 す.すなわち, 図 2 は内部標準としてのフルオライト (f) の (220) 回折線を基準にして, ムライト (m)の (110)
回折線， $\alpha$-アルミナ (a) の (024) 回折線， $\alpha$-クリスト バライト (c) の (101) 回折線の相対強度 (ピーク面積) の変化を示したものである. 4 種の 2 成分系試料のうち ムライトの量論組成になっているのは, $\mathrm{Al}_{2} \mathrm{O}_{3} / \mathrm{SiO}_{2}=$ $3 / 2$ の試料で, そのほかはいずれも過剩の $\mathrm{SiO}_{2}$ を含む. 一般に過剩の $\mathrm{SiO}_{2}$ は焼成中に石英からクリストバライ 卜に変化することが多い。このクリストバライトは試料 の冷却時に約 $200^{\circ} \mathrm{C}$ で $\beta$ 型から $\alpha$ 型へ転移するが, こ のときの体積変化がはなはだ大きいため, 試料中のクリ ストバライトの量が多いと試料にクラックを生じさせた り, 場合によっては破壊を起こすことがある. 本実験で は焼成体を多孔体の前駆体とするため, 久陥のない焼成 体を作製する必要があり，その見地からは試料中のクリ ストバライトが多いことは好ましくない．この実験でも $1400^{\circ} \mathrm{C}$ のときずての試料でクリストバライトを生じ た。クリストバライトの残存の程度は, 過剩の $\mathrm{SiO}_{2}$ が 多い順に大きいが, $\mathrm{Al}_{2} \mathrm{O}_{3} / \mathrm{SiO}$ 比が $1 / 1,3 / 2$ の試料間 ではほとんど差がない，ただし $1400^{\circ} \mathrm{C}$ の焼成ではアル ミナも相当量残っておりムライト化は完全には進んでい ない.

$1500^{\circ} \mathrm{C}$ では, $\mathrm{SiO}_{2}$ 量が多い $\mathrm{Al}_{2} \mathrm{O}_{3} / \mathrm{SiO}_{2}$ 比が $1 / 3.3$ と $1 / 2$ の試料でクリストバライトは残っているが, アル ミナはほぼ消失しており，アルミナのほとんどはムライ トに変わったものと思われる. 一方, これらの試料と比 較して, $\mathrm{Al}_{2} \mathrm{O}_{3}$ 含有量の多い $\mathrm{Al}_{2} \mathrm{O}_{3} / \mathrm{SiO}_{2}=1 / 1,3 / 2$ の 試料では, クリストバライトは消失し $\alpha$-アルミナが残 存した. $\mathrm{Al}_{2} \mathrm{O}_{3} / \mathrm{SiO}_{2}$ 比が $1 / 1,3 / 2$ の試料では $\mathrm{SiO}_{2}$ 量 はムライト組成より多いにもかかわらず，このように $\alpha$-アルミナが残存したが, X 線回折の結果では生成した ガラス量はわずかなため, 未反応の $\mathrm{SiO}_{2}$ が非晶質相と
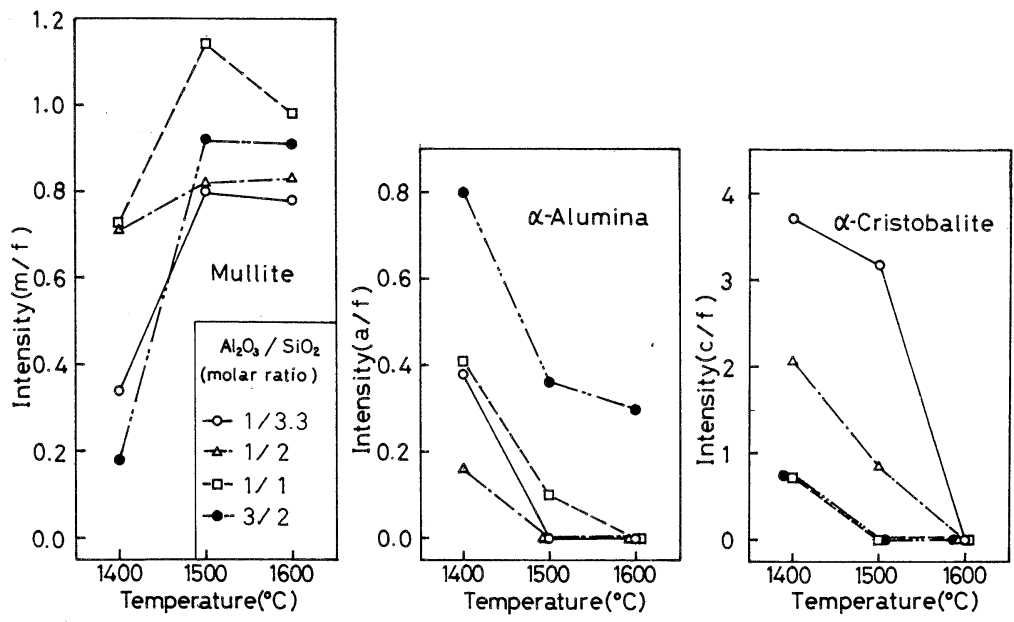

Fig. 2. Changes of relative X-ray intensity of phases in the system $\mathrm{Al}_{2} \mathrm{O}_{3}-\mathrm{SiO}_{2}$ sintered at $1400^{\circ}-1600^{\circ} \mathrm{C}$ for $1 \mathrm{~h}$.

$\mathrm{m}:$ mullite (110), a : $\alpha$-alumina (024), c $: \alpha$-cristobalite (101), f : fluorite (220) 

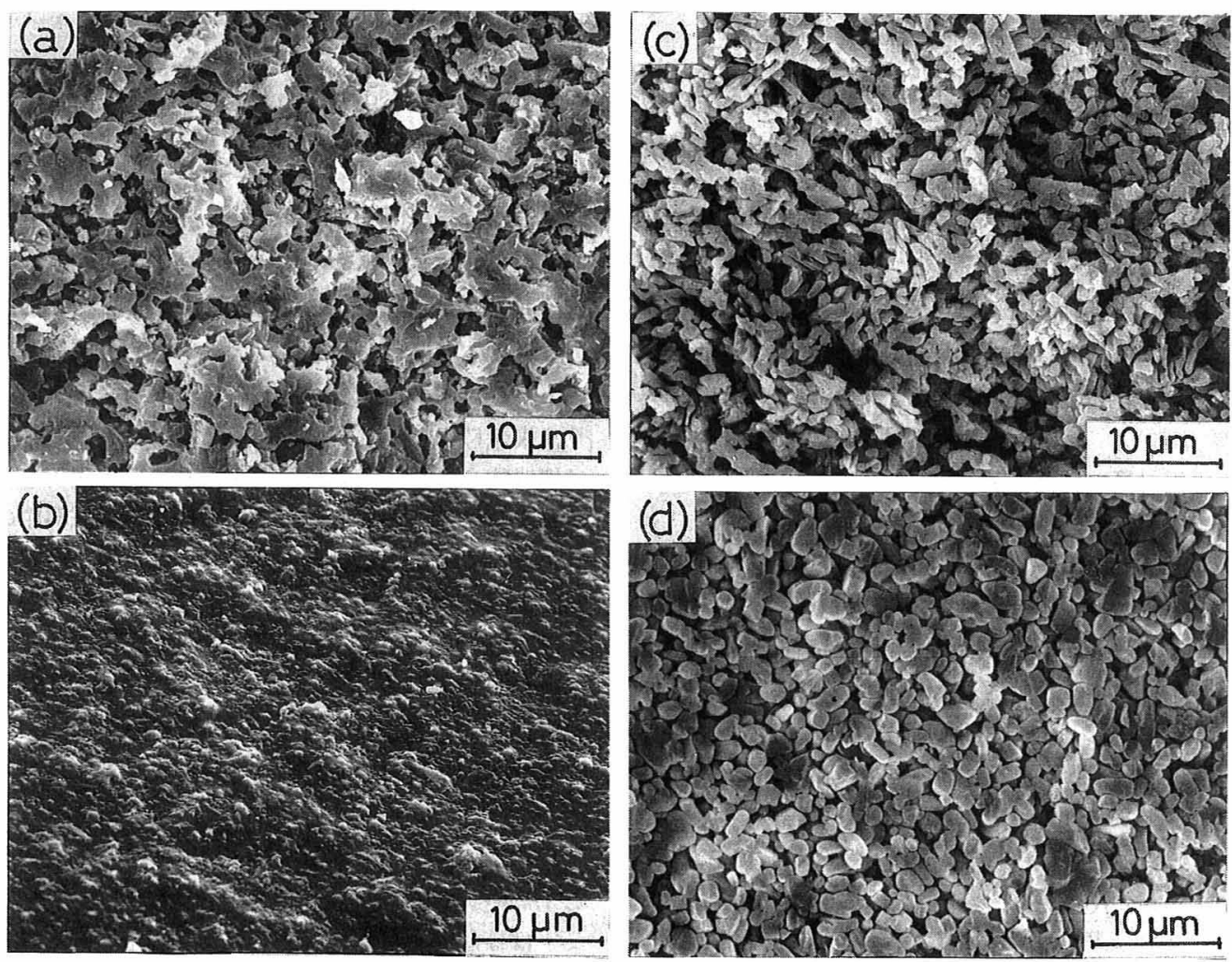

Fig. 3. SEM photographs of the fracture surface of the sintered samples in the system $\mathrm{Al}_{2} \mathrm{O}_{3}-\mathrm{SiO}_{2}$ at $1500^{\circ} \mathrm{C}$ (a) and $1600^{\circ} \mathrm{C}(\mathrm{b})$, and leached samples after sintering at $1500^{\circ} \mathrm{C}$ (c) and $1600^{\circ} \mathrm{C}(\mathrm{d})$.

して存在しているとは考え難い、このことについて, 準 安定状態では $\mathrm{Al}_{2} \mathrm{O}_{3} / \mathrm{SiO}_{2}$ 比が $1 / 2$ や $2 / 1$ のムライトが 存在することが報告されているが81,91, 今回の実験では ムライト粒子の組成について測定を行っていないので, その詳細は明らかではない，平衡状態図によれば $\mathrm{Al}_{2} \mathrm{O}_{3}-\mathrm{SiO}_{2} 2$ 成分系の最低共融点は $1587^{\circ} \mathrm{C}$ である ${ }^{9}$. したがって, $1500^{\circ} \mathrm{C}$ 以下の焼成では液相は生成しない はずであるが, $\mathrm{Al}_{2} \mathrm{O}_{3} / \mathrm{SiO}_{2}=1 / 2$ の試料ではX線回折の 結果, ガラス相が存在していた. 恐らくは微量の不純物 の関与により，液相が若干生成したものと思われるが， その量はわずかで, 物質移動速度が小さいために, 以上 のように末反応の $\mathrm{Al}_{2} \mathrm{O}_{3}$ や $\mathrm{SiO}_{2}$ が残ったものと思われ る.

$1600^{\circ} \mathrm{C}$ 焼成は最低共融点を越えており, 焼成中に液 相が十分に生成したものと推定される.このことは, $1600^{\circ} \mathrm{C}$ ではすべての試料で $\alpha$-クリストバライトが消失 しがラス相になっていることからもうかがえる．このた め $\mathrm{Al}_{2} \mathrm{O}_{3} / \mathrm{SiO}_{2}$ 比が $1 / 1$ の試料では $\alpha-\mathrm{Al}_{2} \mathrm{O}_{3}$ は消失して おり，また $3 / 2$ の試料では減少している.ただしX線回 折で測定したムライトは $1500^{\circ} \mathrm{C}$ の結果と大差はない.

$\mathrm{SiO}_{2}$ 含有量が最も多い $\mathrm{Al}_{2} \mathrm{O}_{3} / \mathrm{SiO}_{2}$ 比が $1 / 3.3$ の試料 の $1500^{\circ} \mathrm{C}$ 上 $1600^{\circ} \mathrm{C}$ 焼成体における酸処理前後の破断
面の電子顕微鏡写真を図 3 に示す。 $1500^{\circ} \mathrm{C}$ 焼成体は気 孔率が $25.2 \%$ で，焼成体に $2 \mu \mathrm{m}$ 以上の大きな気孔が 残っている.したがって処理後の試料の細孔は溶出に よってできた細孔のみではない，一方 $1600^{\circ} \mathrm{C}$ 焼成体で は焼結がよく進行していて気孔は消滅しており, 気孔率

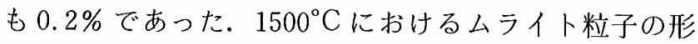

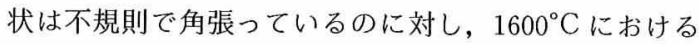
ものは粒状で丸みを帯びている。これは前述のように, ムライト化に関与した液相量の違いによるものであろ う.しかしながら, $1600^{\circ} \mathrm{C}$ 焼成試料では焼成中に多量 の液相が存在しているにもかかわらず，ムライト粒子は 一方向に成長することはなかった。既に種々の $\mathrm{Al}_{2} \mathrm{O}_{3} / \mathrm{SiO}_{2}$ 比の 2 成分系試料において, より高温で長 時間の焼成によれば，ムライト粒子は一方向に成長する ことが報告されている(10),11). したがって今回の実験条件 は焼成の温度が低く，時間も短いために，ムライトの結 晶成長が起こらなかったものと思われる.

図 4 に水銀圧入法により測定した両者の細孔分布を示 す. 細孔分布はよ゙ちらの場合も比較的鋭く, 平均細孔径 はいずれも $0.6 \mu \mathrm{m}$ 付近にある.なお, 前述のように $\mathrm{SEM}$ 観察の結果, $1500^{\circ} \mathrm{C}$ 焼成体の酸処理後の破面で は，2 $2 \mu \mathrm{m}$ 以上の気孔があるようにみえるが (図 $4(\mathrm{~b})$ ), 


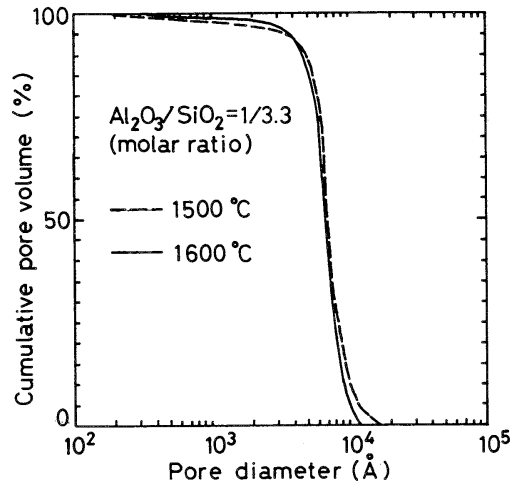

Fig. 4. Pore size distribution of leached samples in the system $\mathrm{Al}_{2} \mathrm{O}_{3}-\mathrm{SiO}_{2}$ sintered at $1500^{\circ}$ and $1600^{\circ} \mathrm{C}$.

この領域は水銀圧入法で正確に測定できる領域ではな

く，両者の結果が一致しなかったものと思われる.

\section{2 第 3 成分添加の効果}

$\mathrm{Al}_{2} \mathrm{O}_{3}-\mathrm{SiO}_{2} 2$ 成分系に第 3 成分を添加すれば系の共 融温度が低下し, 試料の焼結, ムライト化の反応, 過剩 シリカのガラス化, 更にムライト粒子の成長等をより低 温の焼成で行うことができると期待される. そこで, $\mathrm{Al}_{2} \mathrm{O}_{3} / \mathrm{SiO}_{2}=1 / 3.3$ の試料に $\mathrm{TiO}_{2}, \mathrm{Fe}_{2} \mathrm{O}_{3}, \mathrm{MgO}, \mathrm{CaO}$, $\mathrm{BaO}$ の 5 種の酸化物を $5 \mathrm{wt} \%$ 添加し, その効果を調べ た.ここで $\mathrm{Al}_{2} \mathrm{O}_{3} / \mathrm{SiO}_{2}=1 / 3.3$ の組成を選んだのは, ガラス相の量を多くし, その酸処理による多孔体の気孔 率を大きくするためである，種々の焼成条件における 3 成分系試料の構成相の変化を表 1 に示す.また図 5 には, これら 3 成分系焼成体の構成相のうち，ムライト， $\alpha$-ク リストバライト, $\alpha$-アルミナの相対量について, その焼 成温度による変化を示す。 $\mathrm{MgO}, \mathrm{CaO}, \mathrm{BaO}$ の 3 種の アルカリ土類金属酸化物を添加した試料では $\alpha$-クリス
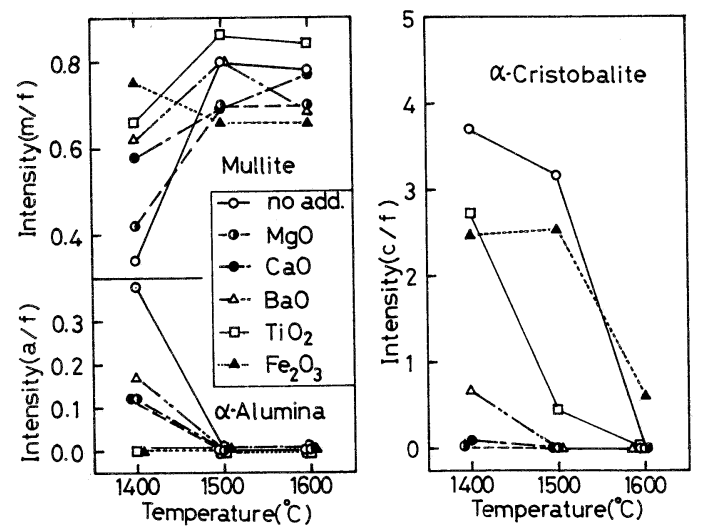

Fig. 5. Changes of relative $\mathrm{X}$-ray intensity of phases in the system $\mathrm{Al}_{2} \mathrm{O}_{3}-\mathrm{SiO}_{2}-\mathrm{M}_{x} \mathrm{O}_{y}$ sintered at $1400^{\circ}-1600^{\circ} \mathrm{C}$ for $1 \mathrm{~h}$.

$\mathrm{m}:$ mullite (110), a : $\alpha$-alumina (024), c: $\alpha$-cristobalite $(101), \mathrm{f}:$ fluorite $(220)$.
Table 1. Phases of the samples in the system $\mathrm{Al}_{2} \mathrm{O}_{3}-\mathrm{SiO}_{2}-\mathrm{M}_{x} \mathrm{O}_{y}$ with composition $\mathrm{Al}_{2} \mathrm{O}_{3} / \mathrm{SiO}_{2}=$ $1 / 3.3$, sintered at $1400^{\circ}-1600^{\circ} \mathrm{C}$. $\mathrm{M}$ : mullite, $\mathrm{Cb}$ : $\alpha$-cristobalite, A : $\alpha$-alumina, Cd : cordierite, An : anorthite, $\mathrm{R}$ : rutile, G : glass phase, -tr : trace

\begin{tabular}{|l|lll|}
\hline MxOY Temp. $\left.{ }^{\circ} \mathrm{C}\right)$ & 1400 & 1500 & 1600 \\
\hline no add. & $\mathrm{Cb}, \mathrm{M}, \mathrm{A}$ & $\mathrm{M}, \mathrm{Cb}, \mathrm{A}$-tr & $\mathrm{M}, \mathrm{G}$ \\
$\mathrm{MgO}$ & $\mathrm{M}, \mathrm{CD}, \mathrm{A}$ & $\mathrm{M}, \mathrm{G}$ & $\mathrm{M}, \mathrm{G}$ \\
$\mathrm{CaO}$ & $\mathrm{M}, \mathrm{Cb}, \mathrm{G}, \mathrm{An}, \mathrm{A}$ & $\mathrm{H}, \mathrm{G}$ & $\mathrm{M}, \mathrm{G}$ \\
$\mathrm{BaO}$ & $\mathrm{H}, \mathrm{Cb}, \mathrm{A}, \mathrm{G}$ & $\mathrm{H}, \mathrm{G}$ & $\mathrm{M}, \mathrm{G}$ \\
$\mathrm{TiO} \mathrm{O}_{2}$ & $\mathrm{H}, \mathrm{Cb}, \mathrm{R}$ & $\mathrm{H}, \mathrm{Cb}, \mathrm{G}, \mathrm{R}-\mathrm{tr}$ & $\mathrm{M}, \mathrm{G}$ \\
$\mathrm{Fe}_{2} \mathrm{O}_{3}$ & $\mathrm{M}, \mathrm{Cb}, \mathrm{A}-\mathrm{tr}$ & $\mathrm{M}, \mathrm{Cb}$ & $\mathrm{M}, \mathrm{Cb}, \mathrm{G}$ \\
\hline
\end{tabular}

トバライトの生成量が少なく, 特に $\mathrm{CaO}, \mathrm{MgO}$ 添加試 料では $1400^{\circ} \mathrm{C}$ の焼成からほとんど消失している.この ことは, $\mathrm{CaO}, \mathrm{MgO}$ 添加試料においては, $1400^{\circ} \mathrm{C}$ 焼成 のとき $\mathrm{SiO}_{2}$ が第 3 成分と反応し，それぞれアノーサイ ト，コーディエライトを生成したためと考えられる。 $\mathrm{BaO}$ 添加の場合も $1500^{\circ} \mathrm{C}$ 焼成では消失している。これ に対し $\mathrm{TiO}_{2}$ と $\mathrm{Fe}_{2} \mathrm{O}_{3}$ を添加した試料では無添加のとき よりはクリストバライト量は少なくなるが，アルカリ土 類金属酸化物添加の場合より多い. $\mathrm{TiO}_{2}$ 添加試料では $1500^{\circ} \mathrm{C}$ 焼成で相当少なくなるが, $\mathrm{Fe}_{2} \mathrm{O}_{3}$ 添加試料では $1600^{\circ} \mathrm{C}$ でも消失しておらず，無添加の場合よりもクリ ストバライトを残しやすいことになる.

$\alpha$-アルミナについては, $\mathrm{TiO}_{2}$ と $\mathrm{Fe}_{2} \mathrm{O}_{3}$ 添加試料では

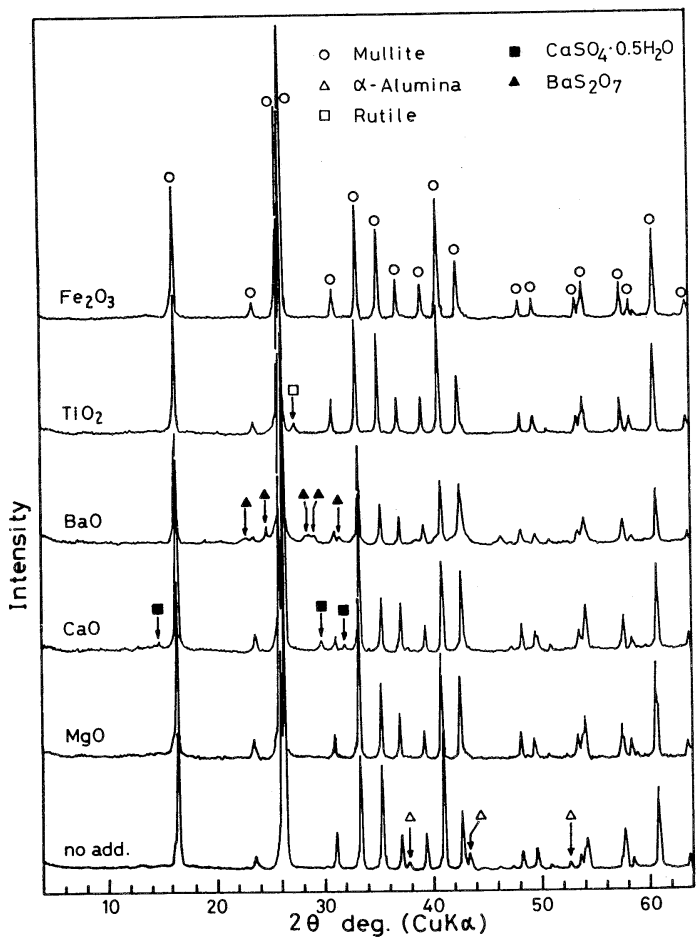

Fig. 6. X-ray diffraction-patterns of leached samples in the system $\mathrm{Al}_{2} \mathrm{O}_{3}-\mathrm{SiO}_{2}-\mathrm{M}_{x} \mathrm{O}_{y}$ sintered at $1500^{\circ} \mathrm{C}$ for $1 \mathrm{~h}$. 

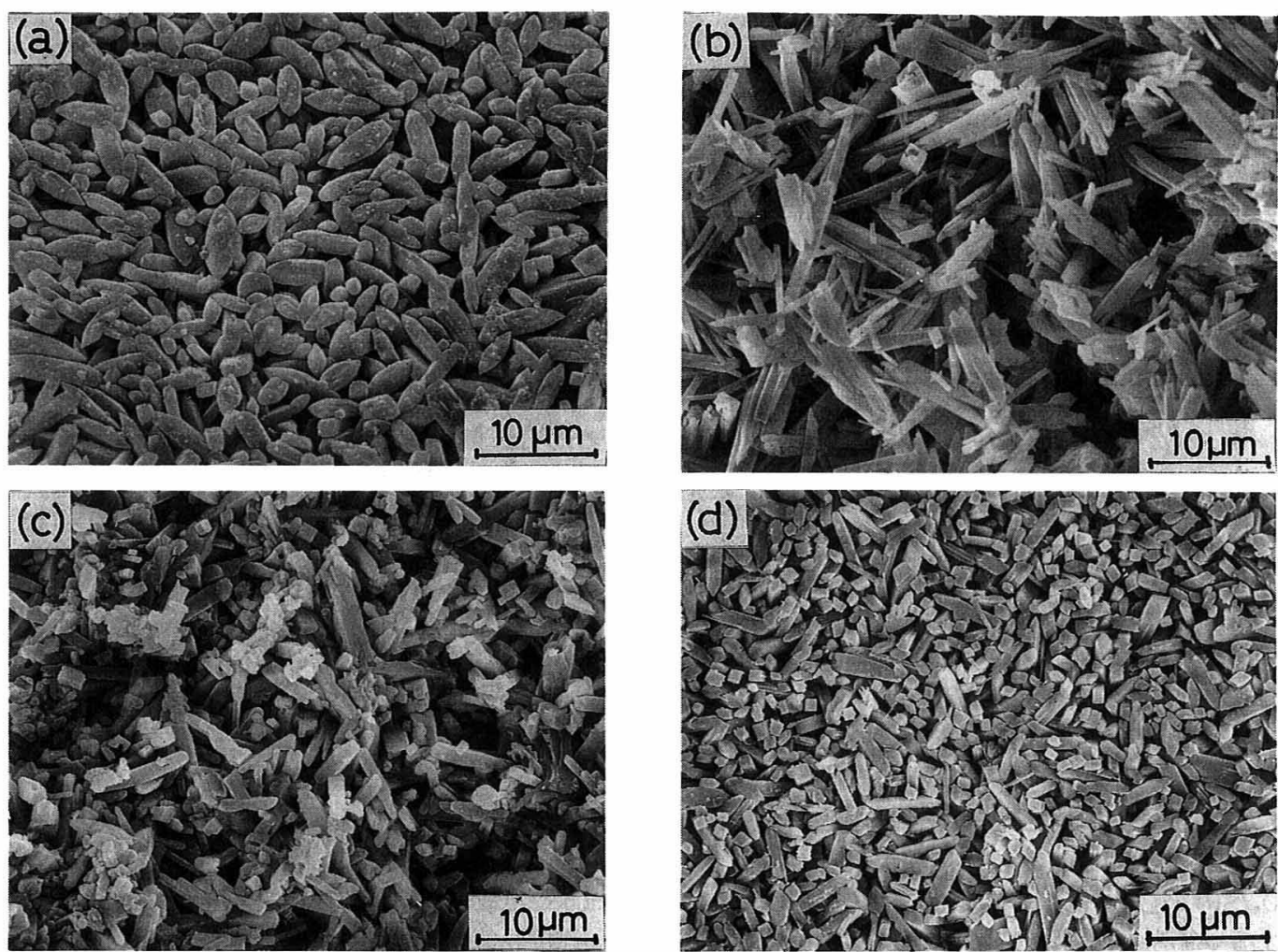

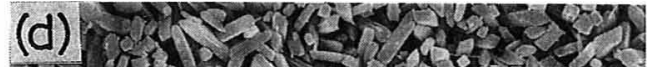

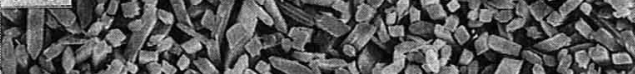

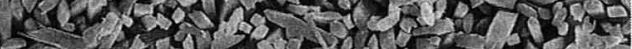

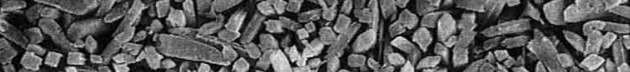

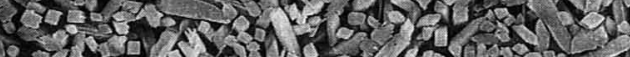

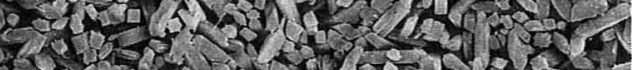

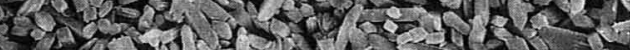

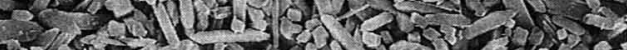

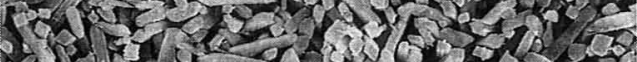

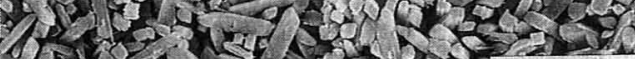

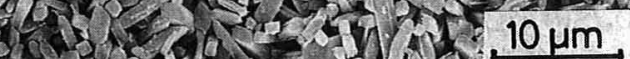
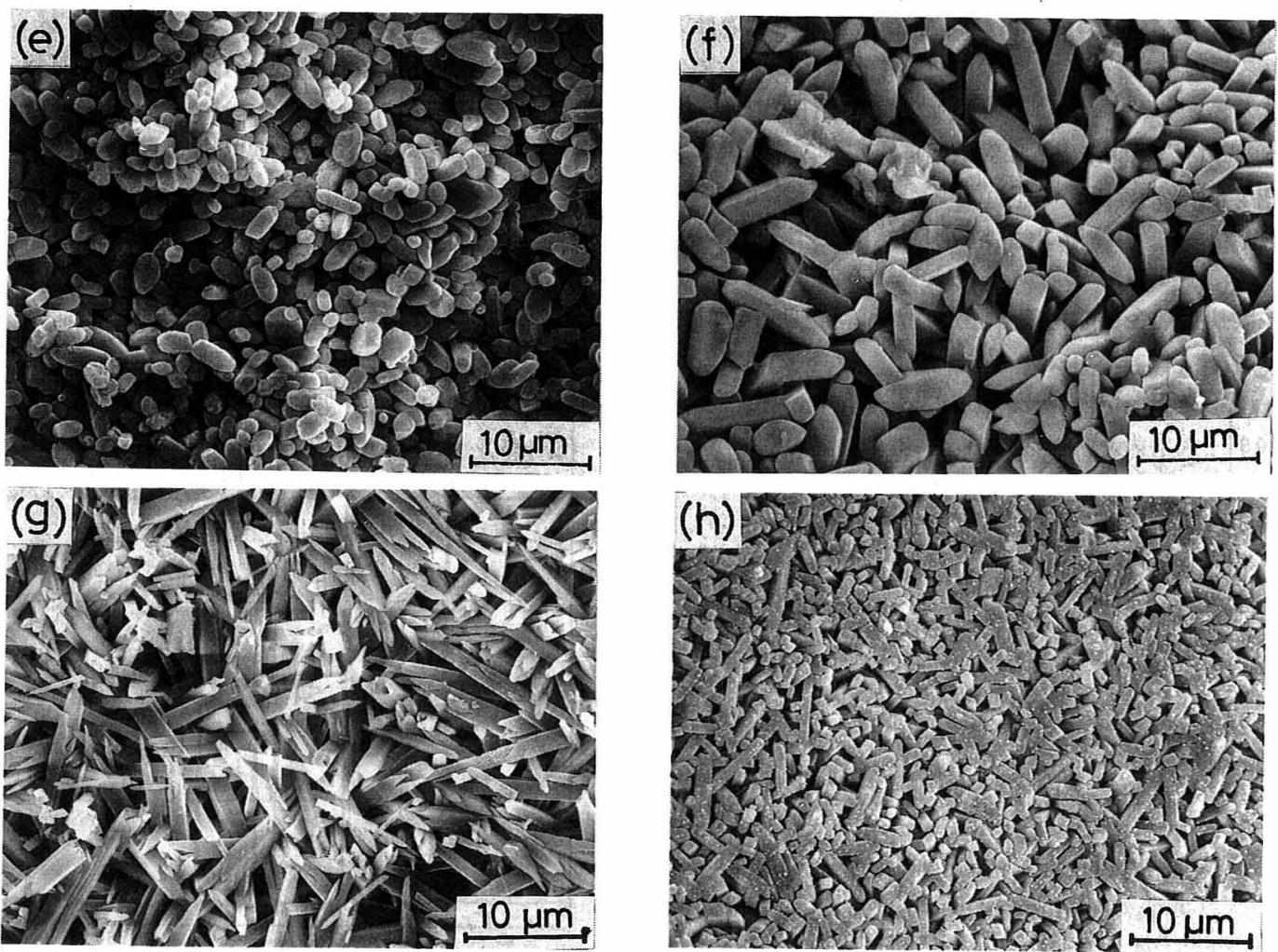

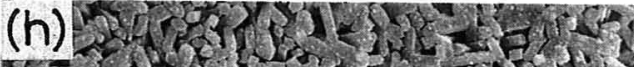

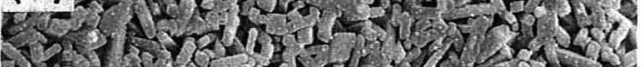

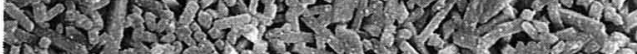
19.

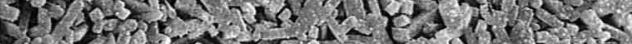

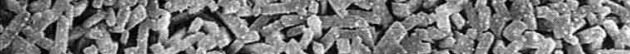

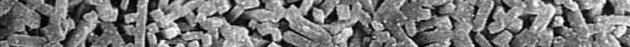

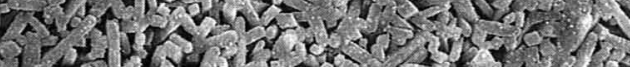
-1)

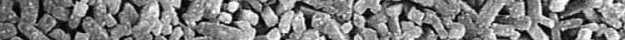

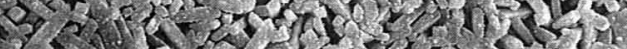

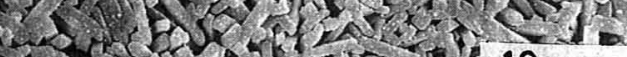
m.

Fig. 7. $\mathrm{SEM}$ photographs of the leached samples in the system $\mathrm{Al}_{2} \mathrm{O}_{3}-\mathrm{SiO}_{2}-\mathrm{M}_{x} \mathrm{O}_{y}$ with composition $\mathrm{Al}_{2} \mathrm{O}_{3}$ / $\mathrm{SiO}_{2}=1 / 3.3$, sintered at $1400^{\circ}-1600^{\circ} \mathrm{C}, \mathrm{M}_{x} \mathrm{O}_{y}-(\mathrm{a}) \mathrm{MgO} \quad\left(1500^{\circ} \mathrm{C}\right), \quad(\mathrm{b}) \mathrm{CaO} \quad\left(1500^{\circ} \mathrm{C}\right), \quad(\mathrm{c}) \mathrm{BaO}\left(1500^{\circ} \mathrm{C}\right)$, (d) $\mathrm{TiO}_{2}\left(1500^{\circ} \mathrm{C}\right)$, (e) $\mathrm{Fe}_{2} \mathrm{O}_{3}\left(1500^{\circ} \mathrm{C}\right)$, (f) $\mathrm{Fe}_{2} \mathrm{O}_{3}\left(1600^{\circ} \mathrm{C}\right)$, (g) $\mathrm{CaO}\left(1400^{\circ} \mathrm{C}\right),(\mathrm{h}) \mathrm{TiO}_{2}\left(1600^{\circ} \mathrm{C}\right)$. 
$1400^{\circ} \mathrm{C}$ で既に残存していないのに対し, アルカリ土類 金属酸化物添加試料ではいずれも残存した。 $\alpha$-アルミナ の残存量の減少はムライトの生成量の増加とほぼ対応し ている。ただし $\mathrm{MgO}$ 添加試料については, $\mathrm{CaO}, \mathrm{BaO}$

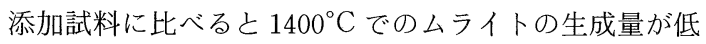
い.このことは前述したコーディエライト相の生成に, $\mathrm{Al}_{2} \mathrm{O}_{3}$ が消費された結果と思われる. $1400^{\circ} \mathrm{C}$ でムライ 卜の生成が最も多かったのは $\mathrm{Fe}_{2} \mathrm{O}_{3}$ 添加試料であるが, 温度の増加とともに生成量が減少するのは他の試料の場 合と異なっている.

3 成分系試料の $1500^{\circ} \mathrm{C}$ 焼成体の, 酸処理後における X線回折パターンを，無添加試料との比較において図 6 に示す. $1500^{\circ} \mathrm{C}$ 焼成試料のうち, アルカリ土類金属酸 化物を添加した焼成体は，既述のようにムライト及びガ ラス相である. 図 6 によれば，酸処理後の試料では，こ のガラス相はほとんど消失しており, 酸処理によって溶 出除去されたものと思われる. ただし $\mathrm{BaO}$ 及び $\mathrm{CaO}$ 添加試料では, ムライト以外の回折ピークが認められる. このうち, $\mathrm{CaO}$ 添加試料のピークは半水セッコウ $\left(\mathrm{CaSO}_{4} \cdot 0.5 \mathrm{H}_{2} \mathrm{O}\right)$ によるものであり, また $\mathrm{BaO}$ 添加 試料のものは二硫酸バリウム $\left(\mathrm{BaS}_{2} \mathrm{O}_{7}\right)$ によるもので あった。いずれも混酸処理によって生成したものである が，その量はわずかである。また， $\mathrm{Fe}_{2} \mathrm{O}_{3}$ 添加試料及び 無添加試料焼成体はムライト，ガラス相のほかにクリス トバライト相を含んでいたが，この場合もムライト相を 残し, 他の相は酸処理によって溶出除去された. $\mathrm{TiO}_{2}$ 添加試料はムライト，ガラス相，クリストバライト相， 及び痕跡量のルチルを含んでいた。酸処理後は $\mathrm{Fe}_{2} \mathrm{O}_{3}$ 添加試料の場合と同様, ガラス相・クリストバライト相 は除去されたが，ムライトとともにルチルは残存した。 なお，無添加の試料はムライト・クリストバライト相の ほかに痕跡量の $\alpha$-アルミナを含んでいたが, 酸処理後

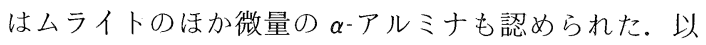
上のことから酸処理によって得られる多孔体はほぼムラ イトから構成されており，ガラス相・クリストバライト 相は溶出されていることが分かる。 また $\alpha$-アルミナ・ ルチル等の結晶相は処理後も残存する.

3 成分系の $1500^{\circ} \mathrm{C}$ 焼成体と一部の $1400^{\circ} \mathrm{C}, 1600^{\circ} \mathrm{C}$ 焼成体について酸処理を行った後の破断面の電子顕微鏡 写真を図 7 に示す. $1500^{\circ} \mathrm{C}$ においては $\mathrm{BaO}, \mathrm{TiO}_{2}$ 添 加試料で短柱状の組織が, また $\mathrm{CaO}$ 添加試料では針 状・木片状の組織が示され, 更に $\mathrm{MgO}$ 添加試料では紡 錘状, $\mathrm{Fe}_{2} \mathrm{O}_{3}$ 添加試料では丸みを帯びた長めの粒状体が それぞれ示された。 $\mathrm{CaO}$ 添加試料では $1400^{\circ} \mathrm{C}$ 焼成体も 既に針状の組織になっている. また $\mathrm{MgO} や \mathrm{Fe}_{2} \mathrm{O}_{3}$ 添加 試料のように $1500^{\circ} \mathrm{C}$ では紡錘状や粒状の結晶粒子も, $1600^{\circ} \mathrm{C}$ で焼成すると短柱状に成長した。しかし $\mathrm{TiO}_{2}$ 添加試料の場合は $1500^{\circ} \mathrm{C} と 1600^{\circ} \mathrm{C}$ 焼成体の間の差異
は少なかった。また， $\mathrm{CaO}, \mathrm{BaO}$ 添加試料では結晶の 成長方向に平行な空洞が存在するものも観察された.こ のように第 3 成分を添加すると, $\mathrm{Al}_{2} \mathrm{O}_{3}-\mathrm{SiO}_{2} 2$ 成分系 と比較し, 概して一方向に成長したムライト結晶が生成 するという特徴を示した.この理由を解明するために, 焼成体の構成相と生成するムライト粒子の形状の関係に ついて検討した.

焼成体中に認められたクリストバライトは焼成中に高 温型石英が変化したものと思われるが，いったん液相に 溶解した場合, 炉冷中に融液からクリストバライトが晶 出することは考え難く，その場合には非晶質になるであ ろう。したがって，焼成体中に認められたクリストバラ イト相は焼成中, 終始固相で存在していた可能性が高い. このことから,クリストバライトの残存が多い試料では, 焼成中に生成した液相の量は少なかったものと考えられ る. 例えば, $1500^{\circ} \mathrm{C}$ 以下の $\mathrm{Fe}_{2} \mathrm{O}_{3}$ 添加試料及び $1400^{\circ} \mathrm{C}$ 焼成における $\mathrm{TiO}_{2}$ 添加試料では, クリストバライトの 残存量が多く液相の量は少なかったものと思われる。こ の原因としては添加成分である $\mathrm{Fe}_{2} \mathrm{O}_{3}$ や $\mathrm{TiO}_{2}$ のムライ トへの固溶が考えられる. 特に $\mathrm{Fe}_{2} \mathrm{O}_{3}$ 添加試料では $\mathrm{Fe}_{2} \mathrm{O}_{3}$ のムライトへの固溶度は大きく ${ }^{12)}$, その結果液相 の生成が少なくなったものと思われる。なお， $\mathrm{Fe}_{2} \mathrm{O}_{3}$ 添 加試料では, $1600^{\circ} \mathrm{C}$ や $1500^{\circ} \mathrm{C}$ よりも $1400^{\circ} \mathrm{C}$ でムライ 卜生成量が多いが, これは焼成温度の増加に伴って, 固 溶していた鉄がムライト結晶の外に排出されること $や^{12)}$, 液相の生成によってムライトが溶解することが原 因と思われる。次に $\mathrm{TiO}_{2}$ 添加試料の場合は, $\mathrm{Fe}_{2} \mathrm{O}_{3}$ 添 加の場合と同様にムライトに固溶することや ${ }^{13), 14)}$, また 添加した $\mathrm{TiO}_{2}$ はルチル相としても残っており, 反応性 に乏しいことが液相の生成を抑制したものと思われる. このようにクリストバライトの残存量が多かった $\mathrm{Fe}_{2} \mathrm{O}_{3}$ 添加の $1400^{\circ} \mathrm{C}, 1500^{\circ} \mathrm{C}$ 焼成試料, 及び $\mathrm{TiO}_{2}$ 添加の $1400^{\circ} \mathrm{C}$ 焼成試料ではムライト粒子は，不規則で粒状の 形態であった。

これに対して, すべての $\mathrm{MgO}, \mathrm{CaO}, \mathrm{BaO}$ 添加試料, $1500^{\circ} \mathrm{C}$ 以上で焼成した $\mathrm{TiO}_{2}$ 添加試料, 及び $1600^{\circ} \mathrm{C}$ で 焼成した $\mathrm{Fe}_{2} \mathrm{O}_{3}$ 添加試料では，クリストバライトの残 存量が少ないが, これは試料中の $\mathrm{SiO}_{2}$ が液相の生成や ムライト化反応，あるいは添加した第 3 成分との反応に 関与したためであり，焼成時に試料中で活発な反応が行 われたことがうかがわれる。これらの試料では，ムライ 卜粒子は一方向に成長する傾向を示しており，特に $\mathrm{CaO}$ 添加試料ではこの傾向が著しかった。

このように，ムライト粒子の一方向への優先的な結晶 成長は添加物の種類と焼成の温度に強く依存している. このことを各供試料の状態図に基づいて考察してみる. 各試料の 3 成分系最低共融点 (E 1), クリストバライ トームライト-S (固相) 系の最低共晶温度または包晶温 
Table 2. The minimum eutectic point (E 1) in the $\mathrm{Al}_{2} \mathrm{O}_{3}-\mathrm{SiO}_{2}-\mathrm{M}_{x} \mathrm{O}_{y}$ system, the eutectic or peritectic point (E 2) in the mullite-cristobalite-S (solid) system and the minimum formation temperature of the two phases mullite and liquid for the tested composition $(\mathrm{M})$ in the system $\mathrm{Al}_{2} \mathrm{O}_{3}-\mathrm{SiO}_{2}-\mathrm{M}_{x} \mathrm{O}_{y}$.

\begin{tabular}{|l|rrrrr|}
\hline HxOy & no add. & Mg0 & Ca0 & Ba0 & $\mathrm{TiO}_{2}$ \\
\hline E1 ( $\left.{ }^{\circ} \mathrm{C}\right)$ & $(1587)$ & 1355 & 1170 & 1122 & 1450 \\
E2 ( $\left.{ }^{\circ} \mathrm{C}\right)$ & $(1587)$ & 1440 & 1345 & 1296 & 1450 \\
H $\left({ }^{\circ} \mathrm{C}\right)$ & $(1587)$ & 1450 & 1400 & 1550 & 1470 \\
\hline
\end{tabular}

度 (E 2), 及び状態図上で供試の組成物がムライト-液 相 2 相共存となる最低温度 $(M)$ を表 2 に示す ${ }^{15) ~ 19) . ~}$ なお, $\mathrm{Al}_{2} \mathrm{O}_{3}-\mathrm{SiO}_{2}-\mathrm{Fe}_{2} \mathrm{O}_{3} 3$ 成分系については状態図が 確立されておらず不明である.

平衡状態図でみるかぎり，E 1 点以下では液相を生成 することはない。ただし，今回の実験では試料は微量の 不純物を含むことから，若干の液相を生成することが考 えられるが，その量はわずかであると推測される．実際 の焼成温度 (反応温度) を表 2 の $\mathrm{E} 1$ 点を比較すると, $\mathrm{MgO}, \mathrm{CaO}, \mathrm{BaO}$ 添加試料では, $1400^{\circ} \mathrm{C}$ で既に液相が 存在しうる条件になっているのに対し， $\mathrm{TiO}_{2}$ 添加の系 では $1400^{\circ} \mathrm{C}$ では液相が存在し得ないか, あるいは上述 のように存在してもわずかな量と思われる。このため十 分な量の液相が存在する場合と比べ，物質移動の速度は 小さく，生成したムライトは不規則で粒状の小さな結晶 の発達にしか至らなかったものと思われる.すなわち， その写真は示していないが, $\mathrm{Al}_{2} \mathrm{O}_{3}-\mathrm{SiO}_{2} 2$ 成分系の液 相量が少ない $1400^{\circ} \mathrm{C}$ と $1500^{\circ} \mathrm{C}$ 焼成の場合 (図 $2(\mathrm{a})$ ) と形態的に類似していた。 また, $\mathrm{Fe}_{2} \mathrm{O}_{3}$ 添加試料の $1400^{\circ} \mathrm{C}$ 焼成の場合も, $\mathrm{TiO}_{2}$ 添加 $1400^{\circ} \mathrm{C}$ 焼成の場合之 類似しており，同様なことが考えられる.

次に反応温度が E 1 E 2 の範囲にある場合である が，E２が共晶点のときは液相を生成することはない。 これは今回の実験では供試組成がムライトの初晶面内に あるからである。しかしながら，E2 点が包晶点のとき には，反応温度が E 1 点を越えたところで液相は存在 し得ると考えられる．ただし，この場合は液相のほかに 2 種類の固相も共存することになる. $\mathrm{MgO}$ 添加試料の $1400^{\circ} \mathrm{C}$ 焼成の場合がこれに相当する。しかし実際には, $\mathrm{X}$ 線回折の結果によれば，試料中にガラス相はなく， 液相は存在してもわずかであったと考えられる. 表 1 に は示していないが， $1300^{\circ} \mathrm{C}$ では既にコーディエライト が生成しており，このことが液相の生成を抑制したこと も考えられる.いずれにしても，この試料の構成粒子は 不規則で小さな粒状の形態であった.

平衡状態図における $\mathrm{E} 2$ 〜 M の温度域では液相は存 在するが, $\mathrm{SiO}_{2}$ の固相も同時に存在する. $\mathrm{BaO}$ 添加試 料の $1400^{\circ} ， 1500^{\circ} \mathrm{C}$ 焼成がこれに当たるが，実際には本
実験の $1500^{\circ} \mathrm{C}$ 焼成試料ではクリストバライト相は消失 し，既にムライトーガラス相になっていた。このときの ムライトは一方向に成長している(図 7 (c)). 一方, $1400^{\circ} \mathrm{C}$ 焼成試料では微細な針状粒子は観察されたもの の，そのほかに不規則で粒状の粒子が大多数を占めてい た．X線回折の結果によれば，この試料のガラス相の 量はわずかで， $\alpha$-アルミナも残っており，このようなこ とがムライト粒子の成長を抑制したものと考えられる. 焼成温度が $\mathrm{M}$ 以上になると平衡状態では固相の $\mathrm{SiO}_{2}$ が なくなる. $1400^{\circ} \mathrm{C}$ 以上の $\mathrm{CaO}$ 添加試料, $1500^{\circ} \mathrm{C}$ 以上 の $\mathrm{MgO}, \mathrm{TiO}_{2}$ 添加試料がこれに該当し, $\mathrm{X}$ 線回折の結 果によっても，各試料ともムライト及びガラス相の 2 相 のみ認められた。これらの試料では, 図 6 に示したよう にムライト粒子が一方向に成長している．以上のことか ら，3成分系においてムライト粒子が成長するためには 試料中に液相が十分に存在することが必要亡思われ，し かもムライト以外の固相が共存しない方が， よく発達し たムライト粒子が得られるようである。固相の存在がム ライト粒子の伸長を立体障害的に抑制していることも考 えられる.また 3 成分系試料を 2 成分系試料と比較する と, 生成した融液には第 3 成分が加わり，これらはいず れも融液の粘度を低下させたことが考えられる．更に同 じ温度で得られる液相の量を平衡状態図から求めると, 3 成分系試料の方が相当に多くなることが分かる．例え ば $\mathrm{Al}_{2} \mathrm{O}_{3} / \mathrm{SiO}_{2}=1 / 3.3$ の 2 成分系試料では $1600^{\circ} \mathrm{C}$ にお いて生成する液相の量は $64 \mathrm{wt} \%$ であるが，これに $\mathrm{CaO}$ を $5 \mathrm{wt} \%$ 添加した試料では液相は $90 \mathrm{wt} \%$ である. このようなことが， 3 成分系において，より低温度かつ 短時間でムライト粒子が一方向に成長した要因と思われ る。なお，針状ムライト結晶の成長方向は，本研究では 同定していないが，天草陶土やカオリンなどの天然原料 を用いた勝木ら ${ }^{20)}$ の結果によれば，[001］の方向となっ ている。

3 成分系試料の $1500^{\circ} \mathrm{C}$ 焼成体における溶出処理後の 細孔分布を図 8 に示す。図 8 の結果は，SEM による粒

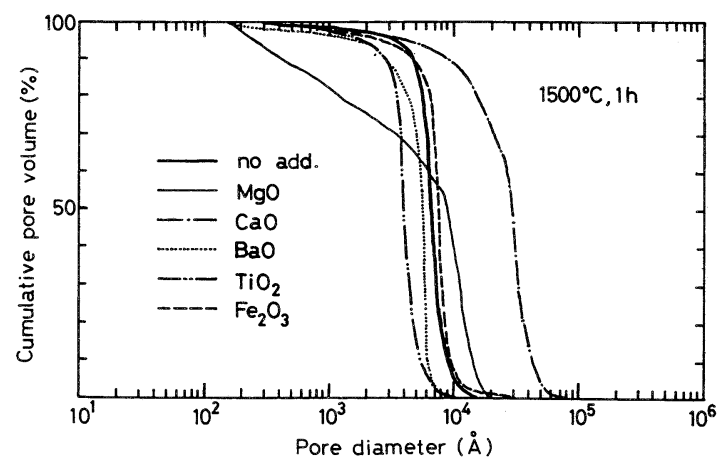

Fig. 8. Pore size distribution of leached samples in the system $\mathrm{Al}_{2} \mathrm{O}_{3}-\mathrm{SiO}_{2}-\mathrm{M}_{x} \mathrm{O}_{y}$ sintered at $1500^{\circ} \mathrm{C}$ for $1 \mathrm{~h}$. 
子形態の観察結果よよく対応している. まず, $\mathrm{CaO}$ 添 加試料の細孔径は $2 \sim 4 \mu \mathrm{m}$ と他の試料に比べ全体的に 大きくなっている．これはこの試料の場合に，針状ある いは木片状の比較的大きなムライト結晶が成長した（図 7 (b)) ことと対応している. 次に, 丸みのある粒状な いしは柱状粒子が生成した $\mathrm{TiO}_{2}, \mathrm{BaO}$, 及び $\mathrm{Fe}_{2} \mathrm{O}_{3}$ 添 加試料では細孔分布は比較的鋭くなっている. 一方, $\mathrm{MgO}$ 添加試料でも類似の粒子形態, 同程度の細孔径の 存在が認められるが，この場合には $1 \mu \mathrm{m}$ から $200 \AA$ ま での細孔も多く, 細孔分布は小さい領域の方に大きくす そをひいている. 他の試料に比べ, $\mathrm{MgO}$ 試料では各結 晶粒子の表面には細かい凹凸がみられ, 恐らく個々の粒 子内部に微細孔が存在しているためであると推察され る. 微細孔部は除外して, 平均細孔径を比較すると, そ の序列は $\mathrm{CaO}>\mathrm{MgO}>\mathrm{Fe}_{2} \mathrm{O}_{3}>$ 無添加 $>\mathrm{BaO}>\mathrm{TiO}_{2}$ 各 添加試料の順になっている。これは SEM 観察によるム ライト粒子の大きさの序列とほぼ一致している．厳密に は, 無添加試料と $\mathrm{BaO}$ 添加試料の序列が逆転している が，その詳細については明らかではない.

\section{4. 結 論}

サブミクロンのアルミナ・シリカ粉体を出発原料とし て得た焼成体のガラス質マトリックスを, 酸処理によっ て除き, ムライト質の多孔体を製造した. 焼成体の構成 相之, 酸処理後の組織について検討した結果, 次のこと が明らかとなった。

(1) $\mathrm{Al}_{2} \mathrm{O}_{3}-\mathrm{SiO}_{2} 2$ 成分系試料における $1500^{\circ} \mathrm{C}$ 以下 の焼成では, 未反応の $\mathrm{Al}_{2} \mathrm{O}_{3}$ や $\mathrm{SiO}_{2}$ が多く, 生成する ムライト粒子は不規則で粒状の形態であった。これは $\mathrm{Al}_{2} \mathrm{O}_{3}$ と $\mathrm{SiO}_{2}$ が固相で反応したか, あるいは液相が存 在しても微量であったためと考えられた。焼成温度が $1600^{\circ} \mathrm{C}$ を超えるとムライト粒子は丸みを帯び，過剩の $\mathrm{SiO}_{2}$ は冷却後ガラス相になった。このことは焼成温度 が $\mathrm{Al}_{2} \mathrm{O}_{3}-\mathrm{SiO}_{2} 2$ 成分系共融点を越え，ムライト粒子の 成長に多量の液相が関与した結果と考えられた。

(2) $\mathrm{Al}_{2} \mathrm{O}_{3}-\mathrm{SiO}_{2}-\mathrm{M}_{x} \mathrm{O}_{y} 3$ 成分系では, 第 3 成分の
種類と焼成温度によって一定ではないものの，概してム ライト粒子が針状に成長する傾向を示した。ムライト粒 子の成長は焼成体の構成相と供試の系の平衡状態図から 判断して, 各試料ともムライト一液相 2 相共存になる温 度以上で著しくなるものと考えられた。

（3）酸処理後の多孔組織の細孔分布はSEM による 観察結果とよく一致した. 平均細孔径は $\mathrm{CaO}>\mathrm{MgO}>$ $\mathrm{Fe}_{2} \mathrm{O}_{3}>$ 無添加 $>\mathrm{BaO}>\mathrm{TiO}_{2}$ の順に大きく, $\mathrm{CaO}$ の 3 $\mu \mathrm{m}$ を除くといずれもサブミクロンの細孔であった。

\section{文献}

1) 木村尚史, ケミカルエンジニアリング， 5 月号， 47-50 (1985).

2) 作花済夫, 化学装置, 3 月号, 52-58 (1985).

3）日置敏美, セラミックス, 20, 168-74 (1985).

4) 懸 欣司, 化学装置, 3 月号, 87-95 (1983).

5）橋本虎雄，化学装置，3月号，96-102 (1983).

6）服部 信, “多孔性セラミックスの開発・応用”, 2 版, シー エムシー (1985) pp.1-11.

7）近藤連一, “多孔材料”, 技報堂 (1973) pp. 55-57.

8) M.N. Rahaman, L. C. De Jonghe, S. L. Shinde and P.H. Tewari, J. Am. Ceram. Soc., 71, C 338-41 (1988).

9) I. A. Aksay and J.A. Pask, J. Am. Ceram. Soc., 58, 507-12 (1975).

10) J. A. Pask and X.W. Zhang, J. Am. Ceram. Soc., 70, 704-07 (1987).

11) M. D. Sacks and J.A. Pask, J. Am. Ceram. Soc., 65, 65-70 (1982).

12) H. Schneider, J. Am. Ceram. Soc., 70, C 43-45 (1987).

13) C. Baudin and J.S. Moya, J. Am. Ceram. Soc., 67, C 134-36 (1984).

14) C. Baudin, M. I. Osendi and J.S. Moya, J. Mater. Sci, Lett., 2, 185-87 (1983).

15) E. M. Levin, C. R. Robbins and H.F. McMurdie, "Phase Diagrams for Ceramists", Vol.1, Ed. by M. K. Reser, The Am. Ceram. Soc., Inc. (1964) p. 123.

16) E. M, Levin, C. R. Robbins and H. F. McMurdie, ibid. (1964) p. 246.

17) E. M. Levin, C. R. Robbins and H. F. McMurdie, ibid. (1964) p. 219

18) E. M. Levin, C. R. Robbins and H. F. McMurdie, ibid. (1964) p. 261.

19) E.M. Levin, H.F. McMurdie, "Phase Diagrams for Ceramists 1975 supplement”, Edited by M. K. Leser, The Am. Ceram. Soc., Inc. (1975) p. 220.

20）勝木宏昭, 古田祥知子, 一八瀬弘道, 中尾 浩, セラミッ クス論文誌, 96, 1081-86 (1988). 